\title{
PENGARUH EKUITAS MEREK TERHADAP KEPUTUSAN PEMANFAATAN PELAYANAN RAWAT JALAN RUMAH SAKIT IBU DAN ANAK ANANDA TRIFA KOTA PAREPARE
}

\author{
The Effect of Brand Equity on the Decision of Utilizing Mother and Children's Hospital \\ Service Ananda Trifa City of Parepare \\ Irma Asriani, Usman, Makhrajani Majid \\ (Program Studi Kesehatan Masyarakat Fakultas Ilmu Kesehatan Universitas Muhammadiyah \\ Parepare) \\ irmaoppoa3s@gmail.com, 082290520341)
}

\begin{abstract}
ABSTRAK
Merek yang kuat akan menjadi daya tarik pelanggan, dengan merek yang kuat, tujuan mengembangkan dan merebut pasar akan lebih mudah tercapai. Dengan demikian Rumah Sakit saat ini harus secara berkelanjutan mengelola ekuitas merek (brand equity) sebagai salah satu intangible asset-nya. Brand equity yang kuat dapat terbentuk melalui kesadaran merek (brand awareness), persepsi kualitas (perceived quality), asosiasi merek (brand association), dan loyalitas merek (brand loyalty). Semakin kuat brand equity suatu produk, semakin kuat pula rasa percaya diri pelanggan dalam proses pengambilan keputusan pembelian, sehingga mengantar perusahaan untuk mendapatkan keuntungan dari waktu ke waktu. Penelitian ini bertujuan untuk mengetahui pengaruh ekuitas merek keputusan pemanfaatan pelayanan rawat jalan di Rumah Sakit Ibu dan Anak Ananda Trifa Kota Parepare. Metode penelitian ini merupakan penelitian kuantitatif. Data diperoleh dengan membagikan kuesioner kepada 45 pasien yang di jadikan sampel mulai bulan Juli sampai Agustus 2018. Analisis penelitian yang digunakan adalah uji chi-square.Hasil penelitian menunjukkan bahwa ada pengaruh yang signifikan antara elemen Brand Awareness, Perceived Qualitye, Brand Asosiasion, Brand Loyalty terhadap keputusan pemanfaatan pelayanan rawat jalan di Rumah Sakit Ibu dan Anak Ananda Trifa
\end{abstract}

Kata Kunci : Kesadaran merek, kesan kualitas, asosiasi merek, loyalitas merek, dan pemanfaatan pelayanan kesehatan

\section{ABSTRACT}

A strong brand will attract customers, with a strong brand, the goal of developing and seizing the market will be more easily achieved. Thus the Hospital now must sustainably manage brand equity (brand equity) as one of its intangible assets. Strong brand equity can be formed through brand awareness, perceived quality, brand association, and brand loyalty. The stronger the brand equity of a product, the stronger the confidence of the customer in the process of purchasing decisions, so that leads the company to get profits from time to time. This study aims to determine the effect of brand equity decisions on the use of outpatient services at Ananda Trifa Mother and Child Hospital, Parepare City. The method of this research is quantitative research. Data were obtained by distributing questionnaires to 45 patients sampled from July to August 2018. The analysis of the research used was the chi-square test. The results showed that there was a significant influence between elements of Brand Awareness, Perceived Quality, Brand Association, Brand Loyalty the decision to use outpatient services at Ananda Trifa Mother and Child Hospital

Keywords : Brand Awareness, perceived quality, asosiasion merek, brand loyalty and utilization of health service 


\section{PENDAHULUAN}

Brand awareness (kesadaran merek) merupakan kemampuan pasien untuk mengenali ataupun mengingat merek rumah sakit. Brand awareness menggambarkan keberadaan merek dalam benak konsumen dan memiliki peranan kunci dalam brand equity didukungoleh penelitian Nugroho (2013) di Rumah Sakit Muhammadiyah Surabaya mengatakan bahwa brand awareness merupakan kunci pembuka untuk memasuki elemen brand equity yang lain. ${ }^{1}$

Perceived quality (kesan kualitas) ini dapat dilihat dari keseluruhan kualitas layanan yang diharapkan pasien diantaranya sarana dan prasarana yang diberikan oleh Rumah Sakit Bersalin. Persepsi kualitas adalah persepsi pelanggan terhadap kualitas atau keunggulan produk atau jasa yang dikaitkan dengan harapan (ekspektasi) pelanggan, didukung dengan penelitian Zefan Adiputra dkk (2013) di Rumah Sakit Universitas Hasanddin Makassar yang mengatakan kualitas yang dirasakan atau dipersepsikan oleh pelanggan akan sangat mempengaruhi keputusan pelanggan untuk membeli atau menggunakan suatu produk dan layanan. ${ }^{2}$

Brand association(asosiasi merek) dimana segala kesan yang muncul dibenak pasien mengenai merek rumah sakit, mencerminkan pencitraan nama rumah sakit dengan kebiasaan, gaya hidup, produk, harga.Asosiasi merek yang kuat memberi citra merek yang kuat terhadap suatu merek. Hal ini sesuai dengan penelitian Rimiyati (2011) di Rumah Sakit PKU Muhammadiyah Gombong yang mengatakan bahwa merek yang selalu konsisten terhadap nilai yang dijanjikan akan memberi citra yang positif di mata konsumen. ${ }^{3}$

Brand loyalty (loyalitas merek), konsumen secara konsisten memanfaatkan pelayanan kesehatan di Rumah Sakit, kesetiaan pasien ini tergantung sejauh mana manfaat dan kualitas dengan harga yang sesuai yang terima pasien. Hal ini didukung oleh penelitian Mulyadi (2012) di Rumah Sakit Islam Karawang yang mengatakan brand loyalty merupakan inti dari brand equity yang menjadi gagasan sentral dalam pemasaran, karena hal ini merupakan satu ukuran keterkaitan seorang konsumen pada sebuah merek. $^{4}$

\section{BAHAN DAN METODE}

Penelitian ini merupakan penelitian kuantitatif menggunakan survey analitk dengan rancangan cross sectional study yaitu suatu rancangan penelitian yang mempelajari pengaruh antara variabel independen(brand awareness, perceived quality, brand association, brnd loyalty) dengan variabel dependen (pemanfaatan pelayanan kesehatan).

Penelitian ini dilakukan di Instalasi Rawat Jalan Rumah Sakit Ibu dan Anak Ananda Trifa Kota Parepare mulai bulan Maret 2018 setelah pengambilan data awal 
sampai dengan selesainya peneltian ini pada akhir bulan Mei 2018. Instrumen yang digunakan adalah kuesioner yang dibagikan kepada pasien rawat jalan di Rumah Sakit Ibu dan Anak Ananda Trifa Kota Parepare selama masa penelitian berlangsung. Adapun jumlah sampel sebanyak 46 responden serta menggunkan analisis data univariat dan bivariat .

\section{HASIL}

Dilihat dari hasil penelitian karakteristik responden berdasarkan umur paling banyak adalah kisaran umur 25-29 tahun yaitu sebesar 18atau (40,0\%), dan paling sedikit yaitu sebesar 13 orang atau $(28,9 \%)$ yang merupakan responden dengan kisaran umur <25 tahun. Karakteristik responden berdasarkan pendidikan terakhir diketahui paling banyak adalah responden menempuh pendidikan sampai SMA/sederajat yaitu sebanyak 21 orang $(46,7 \%)$ dan paling sedikit responden menempuh pendidikan sampai $\mathrm{SD} /$ sederajat yaitu sebanyak 2 orang $(4,4 \%)$. Karakteristik responden berdasarkan pekerjaan diketahui paling banyak responden bekerja sebagai ibu rumah tangga yaitu sebanyak 32 orang $(71,1 \%)$ dan paling sedikit responden bekerja sebagai wiraswasta yaitu sebanyak 4 orang $(8,9 \%)$. Karakteristik responden berdasarkan penghasilan perbulan responden diketahui paling banyak responden berpenghasilan $<1.000 .000$ yaitu sebanyak 29 responden $(64,4 \%)$ dan paling sedikit responden berpenghasilan 1000.000-2000.000 sama 3000.000-4000.000 yaitu sebanyak 4 responden $(8,9 \%) .2$ Mengenai distribusi kesadaran merek responden yaitu sebagian besar menyadari merek yaitu sebanyak 30 responden $(66,7 \%)$ sedangkan yang kurang menyadari sebanyak hanya 15 responden (33,3\%). Mengenai distribusi kesan kualitas responden yaitu sebagian besar kategori tinggi yaitu sebanyak 27 responden $(60,0 \%)$ sedangkan mengenai distribusi asosiasi merek responden yaitu sebagian besar kategori tinggi yaitu sebanyak 25 responden $(55,6 \%)$ sedangkan kategori rendah hanya 20 responden (44.4\%). Kategori rendah sebanyak 18 responden $(40,0 \%)$. Mengenai distribusi loyalitas merek responden yaitu sebagian besar termasuk kategori tinggi yaitu sebanyak 22 responden $(48,9 \%)$ sedangkan loyalitas merek rendah sebanyak 23 responden (51,1 \%). Mengenai distribusi pemanfaatan pelayanan responden yaitu sebagian besar termasuk kategori tinggi yaitu sebanyak 23 responden $(51,1 \%)$ sedangkan pemanfaatan pelayanan rendah hanya 22 responden $(48,9 \%)$.

\section{PEMBAHASAN}

Ditinjau dari kelompok umur pasien menunjukkan bahwa umur pasien pada 
pemanfaatan rawat jalan di Rumah Sakit Ibu dan Anak Ananda Trifa Kota Parepare Tahun 2018 adalah paling banyak pada kisaran umur 25-29 tahun yaitu sebesar 18 orang atau (40,0\%), dan paling sedikit yaitu sebesar 13 orang $(28,9 \%)$ yang merupakan pasien dengan kisaran umur $<25$ tahun. Hasil pengamatan peneliti menunjukkan bahwa pasien yang paling banyak berkunjung merupakan wanita berumur 25-29 tahun. Ini merupakan kisaran umur usia subur dengan melihat mayoritas responden adalah dalam keadaan hamil.

Ditinjau dari pendidikan terakhir pasien menunjukkan bahwa pendidikan terakhir pasien pada pemanfaatan rawat jalan di Rumah Sakit Ibu dan Anak Ananda Trifa Kota Parepare Tahun 2018 paling banyak adalah pasien dengan jenjang pendidikan SMU/sederajat sebanyak 21 orang $(46,7 \%)$. Pasien dengan jenjang pendidikan $\mathrm{SD} /$ sederajat adalah yang paling sedikit yaitu sebanyak 2 orang $(4,4 \%)$. Hasil pengamatan peneliti menunjukkanbahwa pasien yang paling banyak berkunjung yaitu pasien dengan pendidikan terakhir SMA/sederajat sebanyak 21 orang dibandingkan pasien dengan pendidikan terkhir $\mathrm{SD} /$ sederajat sebanyak 2 orang ibu. Ini menunjukkan semakin tinggi pendidikan semakin tinggi pula kesadaran atas pentingnya kesehatan terkait kehamilan dan persalinan. Laij (2012) menyatakan bahwa seseorang dengan pendidikan tinggi cenderung mempunyai demand yang lebih tinggi terhadap pemanfaatan pelayanan kesehatan.
Pendidikan yang lebih tinggi cenderung untuk meningkatkan kesadaran dan konsekuensinya untuk menggunakan pelayanan kesehatan.Masyarakat yang berpendidikan lebih tinggi menganggap penting nilai kesehatan, sehingga akan memanfaatkan jasa kesehatan lebih banyak dibandingkan dengan masyarakat yang pendidikan dan pengetahuannya rendah.

Ditinjau dari jenis pekerjaan responden menunjukkan bahwa pekerjaan ibu pada pemanfaatan rawat jalan di Rumah Sakit Ibu dan Anak Ananda Trifa Kota Parepare Tahun 2018adalah paling banyak ibu rumah tangga sebanyak 32 orang $(71,1 \%)$, dan paling sedikit yaitu pelajar/mahasiswa dan wiraswasta sebanyak $4(8,9 \%)$.

Berdasarkan analisa peneliti selama di lapangan bahwa pasien semua merupakan perempuan yang memiliki pekerjaan IRT, karena pengguna Rumah Sakit Bersalin mayoritas terdiri dari perempuan yang memeriksakan diri terkait dengan KIA.. Selain itu didukung dengan melihat rata-rata ibu memiliki pendidikan terakhir SMA/sederajat. Ibu yang memiliki pendidikan terakhir S1 dan S2 dan bekerja sebagai IRT dikarenakan mereka beberapa ada yang memang belum bekerja sebelum hamil dan adapula yang sengaja berhenti bekerja karna kondisinya yang sedang hamil.

Brand awareness adalah kesanggupan pasien umum yang memanfaatkan pelayanan rawat jalan untuk mengenali, mengingat dan 
mengetahui jenis-jenis layanan yang ditawarkan di Rumah Sakit Ibu dan Anak Ananda Trifa dan menjadikan sebagai pilihan utama.

Hasil penelitian menunjukkan bahwa sebanyak 13 orang $(28,9)$ responden memiliki brand awarenes dengan kategori kurang menyadari dan pemanfaatan pelayanan rawat jalan dengan kategori rendah, dan sebanyak 9 orang $(20,0)$ responden memiliki brand awarenes dengan kategori menyadari dan pemanfaatan pelayanan rawat jalan dengan kategori rendah. Sebanyak 2 orang $(4,4)$ responden memiliki brand awareness dengan kategori kurang menyadari dan pemanfaatan pelayanan kesehatan dengan kategori tinggi.

Ada pula ibu yang yang memanfaatkan pelayanan kesehatan berasal dari luar kota Parepare sehingga beberapa di antaranya beranggapan bahwa Rumah Sakit Ibu Dan Anak Ananda Trifa bukan merupakan salah satu Rumah Sakit Bersalin dan juga beberapa ibu belum mengetahui jenis-jenis pemeriksaan di Rumah sakit ananda Trifa. Mereka mengatakan alasan memanfaatkan pelayanan kesehatan di Rumah Sakit Ibu Dan Anak Ananda Trifa merupakan rekomendasi dari keluarga. Kemudian beberapa yang memiliki kesadaran tinggi tapi pemanfaatannya kurang karena ibu mengaku bahwa untuk sekarang ini hanya sejauh ingin melakukan pemeriksaan kehamilan saja di Rumah Sakit Ibu Dan Anak Ananda Trifa. Ibu mengaku memilih Rumah Sakit Ibu Dan Anak
Ananda Trifa dan mengenal karena merupakan Rumah Sakit Bersalin yang paling dekat dari tempat tinggalnya, sehingga mudah dijangkau.

Kesadaran merek merupakan key of brand asset atau kunci pembuka untuk masuk ke elemen-elemen brand equity lainnya (Nurulaini,2010). Jika kesadaran merek sangat rendah maka kekuatan mereknya juga rendah. Jadi, jika ingin memiliki merek yang kuat hal pertama yang harus dilakukan adalah membuat pelanggan menyadari keberadaan Rumah Sakit Ibu Dan Anak Ananda Trifa karena tingkat penerimaan awal dari seseorang ketika melihat atau mendengar suatu informasi tentang produk beserta mereknya adalah kesadaran akan merek. ${ }^{5}$

Berdasarkan hasil uji statistik diperoleh nilai $\mathrm{p}=0,000$ menunjukkan bahwa ada pengaruh brand awareness dengan pemanfaatan pelayanan oleh pasien rawat jalan di Rumah Sakit Ibu dan Anak Ananda Trifa Kota Parepare Tahun 2018. Hasil dalam penelitian ini sejalan dengan hasil penelitian Nugroho (2013) yang menyatakan brand awareness berhubungan terhadap keputusan masyarakat dalam memilih Rumah Sakit Muhammadiyah Surabaya. Seperti yang dikatakan Durianto dkk. (2004) konsumen cenderung membeli suatu merek yang sudah dikenal, karena dengan membeli merek yang sudah dikenal, mereka merasa aman terhindar dari berbagai resiko pemakaian dengan asumsi bahwa merek yang sudah dikenal bisa lebih diandalkan. ${ }^{6}$ 
Sedangkan penelitian ini tidak sejalan dengan penelitian Setyawati (2015) yang menyatakan bahwa kesadaran merek tidak berpengaruh terhadap keputusan pemilihan Rumah Sakit Gigi dan Mulut Universitas Airlangga ditunjukkan dengan nilai $\mathrm{p}=0,746$ sehingga secara statistic kesadaran merek tidak ada pengaruh. ${ }^{7}$

Berdasarkan analisa peneliti selama di lapangan bahwa ibu yang memanfaatkan Rumah Sakit Ibu dan Anak Ananda Trifa memang sudah pernah memanfaatkan sebelumnya dan adapula rekomendasi dari keluarga yang pernah melakukan persalinan di rumah sakit tersebut dan merasakan kepuasan sehingga menggunakan kembali serta merekomendasikan kepada keluarga yang lain.

Persepsi pasien yang memanfaatkan pelayanan rawat jalan di Rumah Sakit Ibu dan Anak Ananda Trifa tentang unsur kasat mata rumah sakit seperti kelengkapan alat medis, kebersihan, fasilitas fisik rumah sakit, kerapihan dan keramahan staf/karyawan, kehandalan staf/karyawan dalam hal ketepatan waktu pelayanan dan sistem administrasi yang baik, daya tanggap staf/karyawan, perhatian yang ditawarkan oleh tenaga kesehatan rawat jalan di Rumah sakit ibu dan anak ananda trifa.

Hasil penilitian menunjukkan bahwa mengenai pengaruh Perceived Quality dengan Pemanfaatan Pelayanan Rawat Jalan di Rumah Sakit Ibu dan Anak Ananda Trifa menunjukkan bahwa sebanyak 14 orang
$(31,1 \%)$ responden memiliki perceived quality dengan kategori rendah dan pemanfaatan pelayanan rawat jalan dengan kategori rendah dan sebanyak 4 Orang $(8,9 \%)$ responden memiliki perceived quality dengan kategori tinggi dan pemanfaatan pelayanan rawat jalan dengan kategori rendah. Dan sebanyak 8 orang $(17,8)$ responden yang memiliki perceived quality dengan kategori rendah dan pemanfaatan pelayanan kesehatan rawat jalan dengan kategori tinggi dan sebanyak 19 orang $(42,2)$ responden memiliki perceived quality dengan kategori tinggi dan pemanfaatan pelayanan kesehatan dengan kategori tinggi.

Beberapa ibu menilai pelayanan dokter dalam rumah sakit tersebut kurang tepat waktu dalam memberikan layanan kesehatan, jadwal pemeriksaan USG yang biasa berubah.Kemudian adanya beberapa keluhan pasien BPJS yang mengaku dibedakan, hal ini terjadi karna sistem adminustrasi yang dirasakan responden sedikit lama dibandingkan dengan pasien non BPJS. Menyangkut sarana dan pra sarana Rumah Sakit Ibu dan Anak Ananda Trifa beberapa ibu menganggap lokasi parkir kurang memadai (sempit), keluhan pengguna Rumah Sakit Ibu dan Anak Ananda Trifa terutama saat pelayanan rawat jalan yang hanya dibuka pada hari selasa dan jumat artinya dalam seminggu hanya ada dua hari pelayanan rawat jalan yang membuat parkiran dak memadai. Namun beberapa ibu tetap memanfaatkan pelayanan karena sejauh ini secara keseluruhan mereka 
puas dengan pelayanan diberikan karena dokternya yang berkompeten dan perawat yang ramah terhadap pasien. Kemudian beberapa yang memiliki perceived quality tinggi tapi pemanfaatannya kurang karena ibu mengaku aksesnya menuju Rumah Sakit Ibu dan Anak Ananda Trifa jauh dan tinggal di luar Kota Parepare sehingga ke depannya belum tentu untuk memanfaatkan pelayanan di Rumah Sakit Ibu dan Anak Ananda Trifa.

Perceived quality menjadi dasar alasan untuk membeli, jika perceived quality baik maka keputusan pembelian akan tinggi. Mutu pelayanan yang bagus akan berpengaruh pada loyalitas konsumen. Terdapat pengaruh positif antara mutu pelayanan dengan kesetiaan pasien. Meningkat atau menurunnya mutu pelayanan akan diikuti meningkat atau menurunnya kesetiaan pasien ${ }^{8}$.

Berdasarkan hasil uji statistik diperoleh nilai $\mathrm{p}=0,002$ menunjukkan ada pengaruh antara perceived quality dengan pemanfaatan pelayanan rawat jalan di Rumah Sakit Ibu dan Anak Ananda Trifa Kota Parepare Tahun 2018.

Berdasarkan analisa peneliti selama di lapangan bahwa adanya persepsi yang kurang memuaskan dari Masih adanya keluhan pasien BPJS mengeluh terkait sistem administrasi serta lokasi parkir yang kurang memadai. Pelayanan di Rumah Sakit Ibu dan Anak Ananda Trifa sejauh sudah baik karena sebanyak $73,5 \%$ ibu termasuk dalam kategori perceived quality yang tinggi. Ibu mengaku bahwa Rumah Sakit Ibu dan Anak Ananda Trifa memiliki dokter yang berkompeten, perawat yang ramah, staff yang ramah, dan mendengar keluhan pasien dengan baik. Ini menjadi hal yang membuat kesan kualitas Rumah Sakit Ibu dan Anak Ananda Trifa menjadi faktor yang paling berpengaruh dalam pemanfaatan Rumah Sakit Ibu dan Anak Ananda Trifa.

Brand Association adalah ingatan pasien yang berkaitan dengan ciri khas, lokasi, biaya, dan tenaga kesehatan di Rumah Sakit Ibu dan Anak Ananda Trifa sehingga membentuk citra merek dalam pikiran pasien.

Hasil penilitian menunjukkan bahwa mengenai Pengaruh Brand Association Terhadap Pemanfaatan Pelayanan Rawat Jalan di Rumah Sakit Ibu dan Anak Ananda Trifa menunjukkan bahwa sebanyak 18 orang $(40,0)$ responden memiliki brand asosiation dengan kategori rendah dan pemanfaatan pelayanan rawat jalan dengan kategori rendah sebanyak 4 Orang (8,9\%) responden memiliki brand asosiation dengan kategori tinggi dan pemanfaatan pelayanan dengan kategori rendah sebanyak 20 orang $(44,4)$ responden memiliki brand asosiation dengan kategori tinggi dan pemanfaatan pelayanan kesehatan dengan kategori tinggi.

Beberapa ibu menilai Rumah Sakit Ibu dan Anak Ananda Trifa memiliki lokasi yang strategis. Namun mereka mengakui memanfaatkan pelayanan kesehatan di Rumah Sakit ibu dan anak ananda trifa karena telah 
percaya terhadap pelayanan kesehatan yang diberikan.

Asosiasi merek yang baik di mata pelanggan akan membantu mereka dalam memberikan ciri pada merek tertentu, sehingga dapat membedakannya dengan merek lain dalam hal ini membedakan rumahsakit dengan layanan kesehatan lain sehingga akan memudahkan pelanggan dalam membuat keputusan dalam menggunakan jasa layanan kesehatan yang akan mereka pilih saat membutuhkannya.

Asosiasi merek dengan kategori tinggi di mata pelanggan akan membantu pasien dalam membentuk ciri pada suau merek yang akan memudahkan dalam membedakannya dengan merek lain sehingga memudahkan pelanggan dalamn membuat keputusan untuk menggunakan jasa layanan kesehatan yang akan mereka pilih saat dibutuhkan.

Berdasarkan hasil uji statistik diperoleh nilai $\mathrm{p}=0,000$ menunjukkan bahwa ada pengaruh brand association dengan pemanfaatan pelayanan rawat jalan di Rumah Sakit ibu dan Anak Ananda Trifa Kota Parepare Tahun 2018.

Berdasarkan analisa peneliti selama di lapangan bahwa ibu yang mengasosiasikan Rumah Sakit Ibu dan anak ananda trifa sebagai RS Bersalin yang memiliki lokasi kurang strategis tidak terlalu mempertimbangkan terhadap keputusan pemanfaatannya karena sejauh ini ibu merasa puas dengan pelayanan yang diberikan, meskipun sering terjadi keterlambatan pelayaan, namun keramahan perawat staf pegawai merupakan daya tarik konsumen.

Brand loyalty Merupakan tingkat ketertarikan pasien terhadap Rumah Sakit Ibu dan Anak Ananda Trifa sehingga memungkinkan pasien tersebut untuk konsisten, berkomitmen, bangga dan menganggap Rumah Sakit ibu dan anak ananda trifa layak untuk direkomendasikan, serta rela membayar lebih untuk,memanfaatakan pelayanan kesehatan di Rumah Sakit ibu dan anak ananda trifa.

Hasil penelitian menunjukkan bahwa mengenai Pengaruh Brand Loyalty Terhadap Pemanfaatan Pelayanan Rawat Jalan di Rumah Sakit ibu dan anak ananda trifa menunjukkan bahwa sebanyak 19 orang $(42,2 \%)$ responden memiliki brand loyalty dengan kategori rendah dan pemanfaatn pelayanan kesehatan dengan kategori rendah sedangkan sebanyak 3 orang $(6,7)$ responden memiliki brand loyalty dengan kategori tinggi dan pemanfaatan pelayanan kesehatan dengan kategori rendah sebanyak 4 orang $(8,9)$ responden memiliki brand loyalti dengan kategori rendah dan pemanfaatan pelayanan keseshatan dengan kategori tinggi sedangkan sebanyak 19 orang $(42,2)$ memiliki brand loyalty dengan kategori tinggi dengan pemanfaatan pelayanan rawat jalan dengan kategori tinggi.

Beberapa ibu memiliki loyalitas merek rendah memanfaatkan pelayanan kesehatan di Rumah Sakit Ibu Dan Anak 
Ananda Trifa atas dasar kemauan diri sendiri bukan merupakan kebiasaan keluarga. Kemudian adapula ibu yang memanfaatkan karena Rumah sakit ibu dan anak ananda trifa dikarena satu satunya RS terdekat dari tempat tinggalnya. Selanjutnya berdasarkan analisa peneliti terhadap ibu yang menjadi subjek dalam penelitian, ibu akan tetap memanfaatkan pelayanan kesehatan bersalin di Rumah Sakit Ibu Dan Anak Ananda Trifa dan rela membayar lebih mahal untuk memanfaatkan pelayanan karena konsumen mengaku merasa sudah nyaman dengan pelayanan yang diterimanya. Memiliki dokter dokter yang berkompeten dalam bidangnya serta perawat yang ramah. Sehingga sebagian besar ibu merasa puas terhadap pelayanan yang diberikan.

Berdasarkan hasil uji statistik diperoleh nilai $\mathrm{p}=0,000>$ menunjukkan bahwa ada pengaruh antara brand loyalty dengan pemanfaatanpelayanan rawat jalan di Rumah Sakit Ibu dan Anak Ananda Triifa.

Konsumen yang loyal merupakan kunci sukses suatu bisnis atau usaha. Mempertahankan konsumen yang loyal memang harus mendapatkan prioritas yang paling utama daripada mendapatkan pelanggan baru. Hal ini disebabkan untuk merekrut atau mendapatkan pelanggan baru bukanlah hal yang mudah dan memerlukan biaya yang banyak, maka sangatlah rugi jika rumah sakit melepas konsumen yang loyal atau pelanggan begitu saja.
Loyalitas timbul jika tercipta ikatan emosional antara konsumen dengan merek, maka suatu merek akan menjadi lebih unggul dibandingkan dengan merek lainnya karena memiliki ikatan emosional Merek dapat memberikan ikatan emosional jika konsumen mengalami persaan puas pada mebeli atau menggunakan merek (Simamora, 2003). ${ }^{8}$

Berdasarkan analisa peneliti selama di lapangan bahwa pasien yang akan terus memanfaatkan pelayanan Rumah Sakit Ibu dan Anak Ananda Trifa karena merupakan salah satu RS bersalin paling dekat dari tempat tinggalnya. Ada pula ibu yang akan terus memanfaatkan pelayanan karena merasa puas dan nyaman dengan pelayanan di Rumah Sakit Ibu Dan Anak Ananda Trifa.

\section{KESIMPULAN DAN SARAN}

Berdasarkan hasil analisis dan pembahasan yang telah diuraikan pada Bab sebelumnya, maka kesimpulan yang dapat dihasilkan dari penelitian ini adalah ke empat elemen brand equity memilik pengaruh yang signifikan terhadap pemanfaatan pelayanan kesehatan. Dari kesimpulan tersebut disarankan sebaiknya Rumah Sakit Ibu dan Anak Ananda Trifa terus melakukan promosi sehingga nama Rumah Sakit Ibu dan Anak Ananda Trifa nantinya bukan hanya dikenal oleh masyarakat yang pernah memanfaatkan pelayanan tetapi juga dikenalnpada tingkat top ofmind oleh pasien yang akan memanfaatkan pelayanan kesehatan, terus meningkatkan 
kualitas pelayanan yang berorientasi pada kebutuhan pelanggan, ketepetan waktu tenaga medis, dan terus memusatkan perhatian pada upaya mempertahankan pasien yang loyal sehingga diharapkan dapat meningkatkan pemanfaatan pelayanan kesehatan di Rumah Sakit Ibu dan Anak Ananda Trifa. Bagi Penulis selanjutnya diharapkan agar meneliti faktor lain yang dapat mempengaruhi tingkat pemanfaatan pelayanan kesehatan oleh pasien rawat jalan di Rumah Sakit Ibu dan Anak Ananda Trifa.

\section{DAFTAR PUSTAKA}

1. Nugroho. Analisis Pengaruh Brand Equity Terhadap Keputusan Masyarakat Dalam Memilih Rumah Sakit Muhammadiyah Surabaya. 2013. Available at http://download.portalgaruda.org/article .php?article $=90591 \&$ va $\mathrm{l}=1097$

[Diakses pada tanggal 15 Juni 2018].

2. Zefan Adiputra. \& S. A. Paringi. Studi Persepsi Pasien Rawat Jalan Tentang Brand Equity Rumah Sakit Universitas Hasanuddin Tahun 2013; 2013. Available at

http://repository.unhas.ac.id/bitstream/h andle/123456789/5695/jurnal.p

$\underline{\text { df; } \text { sequence }=1}$ [Diakses pada tanggal 15 Juni 2018].

3. Rimiyati. Analisis Elemen-Elemen Brand Equity RumahSakit PKU Muhammadiyah Gombong.
2011.Available at http://journal.umy.ac.id/index.php/mrs/a rticle /view/1146/1216 [Diakses pada tanggal 15 Juni 2018].

4. Mulyadi.D. Pengaruh Ekuitas Merek Terhadap Kinerja Pemasaran Pada Rumah Sakit Islam Karawang. 2012. Available at http://feunsika.ac.id/Jurnalonline/wp content/uploads/2015/ 12/DEDI-UUS-090412.pdf [Diakses pada tanggal 15 Juni 2018].

5. Nurulaini, N. Analisa Brand Equity Rumah Sakit Islam Jakarta Menurut Persepsi Pelanggan Rawat Jalan Di Empat Layanan Dasar Pada Tahun 2010 (Tesis). Universitas Islam Depok; 2010.

6. Durianto,D. Sugiarto, Sitinjak, T.Strategi Menaklukkan Pasar Melalui Ekuitas Merek dan Perilaku Merek. Jakarta: PT. Gramedia Pustaka Indonesia; 2004.

7. Setyawan.D\& A. Hapsari. Pengaruh Manfaat Merek, Kekuatan Asosiasi Merek, Dan Keunikan Merek Terhadap Loyalitas Konsumen Dalam membeli Air Muman Kemasan Merek. 2012.

8. Setyawati, C., \& Rochmah, T. N. Pengaruh Brand Knowlegde terhadap Pemilihan Rumah Sakit.Jurnal Administrasi Kesehatan Indonesia (1); 2015. 
9. Simamora, B. Tujuh Langkah Membangun Merek. Jakarta: Gramedia; 2001.
10. Simamora. Aura Merek (7 langkah membangun merek yang kuat). Jakarta: Gramedia Pustaka Utama; 2013. 


\section{LAMPIRAN}

Tabel 1 Distribusi pasien berdasarkan Brand Awareness terhadap Pemanfaatan Pelayanan Rawat Jalan Rumah Sakit Ibu Dan Anak

Ananda Trifa Kota Parepare Tahun 2018

\begin{tabular}{|c|c|c|c|c|c|c|c|}
\hline \multirow{3}{*}{ Kesadaran merek } & \multicolumn{4}{|c|}{$\begin{array}{c}\text { Pemanfaatan } \\
\text { pelayanan }\end{array}$} & \multirow{2}{*}{\multicolumn{2}{|c|}{ Total }} & \multirow[b]{3}{*}{ Nilai P values } \\
\hline & \multicolumn{2}{|c|}{ Tinggi } & \multicolumn{2}{|c|}{ Rendah } & & & \\
\hline & $\mathrm{n}$ & $\%$ & $\mathrm{n}$ & $\%$ & $\mathrm{n}$ & $\%$ & \\
\hline Menyadari & 21 & 46,7 & 9 & 20,0 & 30 & 66,7 & \\
\hline Kurang menyadari & 2 & 4,4 & 13 & 28,9 & 15 & 33,3 & 0,000 \\
\hline Total & 23 & 51,1 & 22 & 48,9 & 45 & 100,0 & \\
\hline
\end{tabular}

Tabel 2 Distribusi pasien berdasarkan Perceived Quality terhadap Pemanfaatan Pelayanan Rawat Jalan Rumah Sakit Ibu Dan Anak Ananda Trifa Kota Parepare Tahun 2018

\begin{tabular}{|c|c|c|c|c|c|c|c|}
\hline \multirow{3}{*}{ Percived quality } & \multicolumn{4}{|c|}{ Pemanfaatanpelayanan } & \multirow{2}{*}{\multicolumn{2}{|c|}{ Total }} & \multirow{3}{*}{ Nilai $P$ values } \\
\hline & \multicolumn{2}{|c|}{ Tinggi } & \multicolumn{2}{|c|}{ Rendah } & & & \\
\hline & $\mathrm{n}$ & $\%$ & $\mathrm{n}$ & $\%$ & $\mathrm{n}$ & $\%$ & \\
\hline Tinggi & 19 & 42,2 & 8 & 17,8 & 27 & 60 & \\
\hline Rendah & 4 & 8,9 & 14 & 31,1 & 18 & 40 & 0,002 \\
\hline Total & 23 & 51,1 & 22 & 48,9 & 45 & 100 & \\
\hline
\end{tabular}

Tabel 3 Distribusi pasien berdasarkan Brand Asosiation terhadap Pemanfaatan Pelayanan Rawat Jalan Rumah Sakit Ibu Dan Anak Ananda Trifa Kota Parepare Tahun 2018

\begin{tabular}{|c|c|c|c|c|c|c|c|}
\hline \multirow[t]{3}{*}{$\begin{array}{l}\text { Brand } \\
\text { asosiation }\end{array}$} & \multicolumn{4}{|c|}{$\begin{array}{l}\text { Pemanfaatan } \\
\text { pelayanan }\end{array}$} & & \multirow[b]{2}{*}{ Total } & \multirow{3}{*}{ Nilai P values } \\
\hline & \multicolumn{2}{|c|}{ Tinggi } & \multicolumn{2}{|c|}{ Rendah } & & & \\
\hline & $\mathrm{n}$ & $\%$ & $\mathrm{n}$ & $\%$ & $\mathrm{n}$ & $\%$ & \\
\hline Tinggi & 20 & 44,4 & 5 & 11,1 & 25 & 55,6 & \\
\hline Rendah & 3 & 6,7 & 17 & 37,8 & 20 & 44,4 & 0,000 \\
\hline Total & 23 & 51,1 & 22 & 48,9 & 45 & 100,0 & \\
\hline
\end{tabular}


Tabel 4 Distribusi pasien berdasarkan Brand Loyality terhadap Pemanfaatan Pelayanan Rawat Jalan Rumah Sakit Ibu Dan Anak Ananda Trifa Kota Parepare Tahun 2018

\begin{tabular}{|c|c|c|c|c|c|c|c|}
\hline \multirow[t]{3}{*}{ Brand loyalty } & \multicolumn{4}{|c|}{ Pemanfaatanpelayanan } & & & \multirow{3}{*}{ Nilai $P$ values } \\
\hline & \multicolumn{2}{|c|}{ Tinggi } & \multicolumn{2}{|c|}{ Rendah } & \multicolumn{2}{|c|}{ Total } & \\
\hline & $\mathrm{n}$ & $\%$ & $\mathrm{n}$ & $\%$ & $\mathrm{n}$ & $\%$ & \\
\hline Tinggi & 19 & 42,2 & 3 & 6,7 & 22 & 48,9 & 0,000 \\
\hline Rendah & 4 & 8,9 & 19 & 42,2 & 23 & 51,1 & \\
\hline Total & 23 & 51,1 & 22 & 48,9 & 45 & 100,0 & \\
\hline
\end{tabular}

